\title{
Mirosław Romański
}

Rzeszów

\section{Polski eksport \\ na tle polityki ekonomicznej USA w latach 1945-1967}

Tematyka współpracy gospodarczej między Stanami Zjednoczonymi a Polską po II wojnie światowej była już podejmowana w różnych aspektach przez wielu autorów. Trzeba jednak zauważyć, że większość prac odwołuje się do polityki i dyplomacji obu krajów, a kwestie gospodarcze omówione są na ogół wśród innych aspektów. Ową problematykę poruszali m.in.: M. Salamaga', S. Wydymus $^{2}$, L. Jasiński ${ }^{3}$, A. Mania ${ }^{4}$, M. Nytko ${ }^{5}$ L. Pastusiak 6 , D. Allen 7 , J. Tyszkiewicz $^{8}$, W. Bieńkowski ${ }^{9}$, R. Ludwikowski ${ }^{10}$. Istnieją też starsze pozycje, ale z uwagi na odległy czas ich wydania, wiele informacji tam zawartych nie ma odniesienia do współczesnego stanu wiedzy ${ }^{11}$.

1 M. Salamaga, Modelowanie wptywu bezpośrednich inwestycji zagranicznych na handel zagraniczny w świetle wybranych teorii ekonomii na przykładzie krajów Europy Środkowo-Wschodniej, Kraków 2013.

2 S. Wydymus (red.), Bezpośrednie inwestycje zagraniczne a konkurencyjność eksportu Polski, Warszawa 2012.

3 L. Jasiński, Blizej centrum czy na peryferiach? Polskie kontakty gospodarcze z zagranica w XX wieku, Warszawa 2011.

4 A. Mania, Department of State 1789-1939. Pierwsze 150 lat udziału w polityce zagranicznej USA, Kraków 2011.

5 M. Nytko, Instrumenty finansowania rozwoju eksportu w Polsce, Kraków 2009.

6 L. Pastusiak, Stosunki polsko-amerykańskie 1945-1955, Torun 2004.

7 D. J. Allen, The Oder-Neisse line: the United States, Poland and Germany in the Cold War, Westport 2003.

8 J. Tyszkiewicz, Otwarte okno $w$,żelaznej kurtynie”. Polityka administracji prezydenta Eisenhowera wobec Polski (październik 1956-1961), Wrocław 2003.

9 W. Bieńkowski, Reaganomika i jej wpływ na konkurencyjność gospodarki amerykańskiej, Warszawa 1995.

10 R. Ludwikowski, Ameryka - świat biznesu: 250 pytań $i$ odpowiedzi na temat handlu międzynarodowego, Kraków 1991.

11 Np.: E. Rokicka, Główne kierunki aktywności Stanów Zjednoczonych wokót spraw polskich, Warszawa 1985; L. Zyblikiewicz, Polityka USA i Anglii wobec Polski 1944-1949, Warszawa 1984; 
Podstawą źródłową do przygotowania artykułu były w głównej mierze dokumenty wytworzone przez Wydział Zagraniczny KC PZPR oraz Ministerstwo Spraw Zagranicznych, które zdeponowane są w Archiwum Akt Nowych w Warszawie. Rolę pomocniczą odegrały też inne źródła niezbędne do analizy problematyki, jak roczniki statystyczne, dzienniki ustaw, biuletyny itp.

Chronologię przyjętą $\mathrm{w}$ artykule nieprzypadkowo skoncentrowano na latach 1945-1967. Ma ona podwójne odniesienie - w wypadku Stanów Zjednoczonych mamy do czynienia z dwoma okresami polityki ekonomicznej tego kraju wobec Polski, które najogólniej podzielić można na lata 1945-1960, i 1961-1967. Poprawne byłoby również przyjęcie jako daty początkowej roku 1947, kiedy miał miejsce plan Marshalla służący odbudowie gospodarek państw Europy Zachodniej po II wojnie światowej ${ }^{12}$. Jednak z uwagi na to, że współpraca w dziedzinie wymiany towarowej USA z Polską istniała tuż po wojnie, jako datę początkową przyjęto rok 1945. Zestawienie obu okresów jest tym bardziej zasadne, bo znacznie się między sobą różniły. W drugim przypadku, czyli Polski, analizowany okres przypada na rządy Bieruta i Gomułki. Zasadniczym celem jest jednak ukazanie różnic pomiędzy poziomem wymiany handlowej lat pięćdziesiątych i sześćdziesiątych. Decydującą rolę miało anulowanie Polsce „klauzuli najwyższego uprzywilejowania" i widoczne w latach 1962-1967 pogorszenie wymiany handlowej.

Politykę ekonomiczną Stanów Zjednoczonych po zakończeniu działań wojennych charakteryzowała dwutorowość. Dyplomacja USA zaangażowana w likwidowanie skutków wojny koncentrowała się na niechęci do nadmiernego zaostrzania konfliktu z ZSRR, oraz zabiegów podtrzymania współpracy z niedawnym sojusznikiem. Jednak zasadniczym celem polityki USA wobec Europy w pierwszych latach powojennych, była pomoc w odbudowie jej gospodarki i przeciwdziałanie polityczne podziałowi kontynentu. Przyjęto zatem plan Marshalla przeznaczając w ciągu dwóch lat powojennych dla państw europejskich bezzwrotną pomoc kredytową 9,3 mln dolarów ${ }^{13}$. Kraje Europy poza tym były ponadto w około 80\% odbiorcami bezzwrotnej pomocy żywnościowej, leczniczej oraz mieszkaniowej, udzielonej przez Organizację Narodów Zjednoczonych do Spraw Pomocy i Odbudowy. Trzeba dodać, że straty i zniszczenia zakładów produkcyjnych wywołane wojną, duży stopień amortyzacji ocalałych urządzeń przemysłowych, brak węgla i stali, oraz zerwanie tradycyjnych powiązań handlowych,

J. Kropiwnicki, Teoria automatycznych stabilizatorów koniunktury, Warszawa 1976; W. Jurasz, Wptyw zagranicznej polityki ekonomicznej USA na rozwój polskiego eksportu do Stanów Zjednoczonych w latach 1946-1967, Warszawa 1971; D. Staševskij, Interwencja pod pozorem pomocy: działalność misji żywnościowych Stanów Zjednoczonych w Polsce, Warszawa 1964.

12 M. Hogan, The Marshall Plan America, Britain, and the reconstruction of Western Europe, 1947-1952, Cambridge 1987, s. 18-30.

13 W. Roszkowski, Półwiecze. Historia polityczna świata po 1945 roku, Warszawa 1997, s. 32-33. 
w znacznym stopniu wpłynęły na zmniejszenie produkcji i poważnie ograniczyły eksport. Jego wartość do państw Europy Zachodniej była w chwili przyjęcia planu Marshalla o $41 \%$ niższa niż tuż przed II wojną światową. Miał tutaj znaczenie brak rezerw złota i dewiz w dolarach, co z kolei powiększało trudności płatnicze i zmniejszało zdolności importowe w stosunkach ze strefą dolarową. W Stanach Zjednoczonych stopniowo zdawano sobie sprawę, że amerykańskie wyobrażenia na temat sytuacji gospodarki Europy były przesadnie optymistyczne ${ }^{14}$. Naciskano wobec tego na rozpoczęcie wewnątrzeuropejskiej współpracy gospodarczej jako metody wyjścia z kryzysu ${ }^{15}$.

Elementem nadmienionej współpracy było szybkie nawiązanie kontaktów handlowych z Polską, która tuż po II wojnie światowej znalazła się w zupełnie nowej sytuacji politycznej, społecznej i ekonomicznej. Sytuacja ta nie mogła pozostać bez wpływu na rozwój polskiej wymiany gospodarczej z zagranicą - przy czym podstawowe tendencje tego rozwoju zarysowywać zaczęły się szybko po zakończeniu działań wojennych. Zasadnicza reorientacja polskiego handlu zagranicznego, podyktowana zarówno względami ekonomicznymi jak i politycznymi, stała się faktem już w pierwszych latach powojennych ${ }^{16}$. Do głównych partnerów gospodarczych Polski z oczywistych względów należał Związek Radziecki i jego kraje satelickie skupione w Europie Środkowo-Wschodniej. Współpraca ta dokonywała się przy wyraźnym zmniejszeniu roli wymiany handlowej z krajami kapitalistycznymi w życiu gospodarczym Polski zwłaszcza w drugiej połowie lat pięćdziesiątych XX w. Na sytuację tę złożył się kompleks czynników zewnętrznych i wewnętrznych, które miały bezpośredni wpływ na ukształtowanie się wielkości oraz struktury eksportu ze Stanami Zjednoczonymi i innymi krajami demokratycznymi ${ }^{17}$. Stany Zjednoczone wyszły z II wojny światowej ze swoją gospodarką praktycznie nienaruszoną. Żadna z gałęzi przemysłu nie uległa dewastacji, a ekonomia tego kraju nie musiała tak jak gospodarki innych państw, przechodzić długiego okresu odbudowy, modernizacji, a także wymiany maszyn i sprzętu ${ }^{18}$.

Rozwój współpracy gospodarczej między Polską a Stanami Zjednoczonymi w pierwszych latach po wojnie formalnie opierał się na „Traktacie o Przyjaźni, Handlu i Prawach Konsularnych", który został podpisany dnia 15 VI 1931 r.

14 P. Kobza, Transatlantyckie Partnerstwo na rzecz. Handlu i Inwestycji. Nowy regionalizm atlantycki? „Studia Europejskie” 2013, nr 3, s. 31-38.

15 K. Dominik, Rola $i$ znaczenie Planu Marshalla, http://www.up.krakow.pl/konspekt/34/ index.php?i=028 (07-01-2014).

16 The American Review of Soviet and Eastern European Foreign Trade, vol. 2, November-December 1966, s. 10-16.

17 H. Więckowski, Doktryna a handel, cz. 1, „Handel Zagraniczny”, 1966, nr 3, s. 87.

18 Sytuacja w Stanach Zjednoczonych, „Biuletyn Informacji Specjalnej” 1950, nr II, (73) z listopada-grudnia, s. 29. 
w Waszyngtonie jeszcze przez władze II $\mathrm{RP}^{19}$. Art. VI tego dokumentu stanowił m.in., że Rzqd USA nie wprowadzi ani nie będzie utrzymywał w mocy ograniczeń importu z terytorium lub eksportu do terytorium drugiej strony, które nie sq stosowne do importu i eksportu takiego samego artykutu, pochodzqcego lub wysyłanego do jakiegokolwiek innego kraju ${ }^{20}$. Artykuł ten był podstawą prawną wzajemnego zastosowania tzw. „klauzuli najwyższego uprzywilejowania” w stosunkach handlowych Polski ze Stanami Zjednoczonymi. Z formalno-prawnego punktu widzenia Polska rozpoczęła odbudowę handlu z USA, posiadając wyżej wspomnianą klauzulę, co było szczególnie istotne z uwagi na wysoki poziom stawek celnych w Ameryce bez jej stosowania. Przystępując do odbudowy stosunków handlowych z USA po przerwie w okresie II wojny światowej, Polska nie posiadała tradycji wysokiego poziomu obrotów z USA. Tuż przed wojną wartość jej eksportu do Ameryki oszacowano na 11,9 mln dolarów, co stanowiło około $5,3 \%$ polskiego eksportu ogółem ${ }^{21}$.

Zarówno wielkość, jak i wysoce ograniczony asortyment eksportu do USA przed wojną nie pozostały bez wpływu na kształtowanie się polskiego eksportu w pierwszych latach powojennych. Po zakończeniu działań wojennych w okresie odbudowy zniszczonej gospodarki polskiej, eksport Polski do USA był niewielki, mniejszy od importu towarów z tego kraju. W roku 1946 Polska zakupiła wyroby gotowe i surowce za około 1,6 mln dolarów sprzedając jednocześnie swoje towary. Odbudowa eksportu Polski, która rozpoczęła się już w 1946 r., napotkała na zasadnicze trudności wewnętrzne wynikające z ogromu nadmienionych zniszczeń jak również zmiany struktury gospodarki narodowej w rezultacie przesunięcia granic państwowych. W latach 1946-1950 dokonano dużego wysiłku eksportowego ${ }^{22}$. O ile w $1946 \mathrm{r}$. opiewał on ogółem na sumę $0,3 \mathrm{mln}$, o tyle w 1949 r. było to już 4,1 mln dolarów ${ }^{23}$. Spory wysiłek eksportowy doprowadził do osiągnięcia już w 1950 r. poziomu 11 mln dolarów eksportu do USA. Jego struktura pozostawała nadal bardzo wąska, zatem z oczywistych względów wewnętrzno-gospodarczych Polski nie odbiegała od struktury eksportu przedwojennego. Jeśli chodzi o asortyment, do USA wysyłano w zasadzie te same towary co przed wojną - szynkę, łopatki, cykorię oraz skóry zwierzęce. Wyroby te stanowiły po wojnie $80-90 \%$ eksportu Polski do USA. Z uwagi na charakter gospodarki Polski w latach odbudowy zniszczeń wojennych i planu 3-letniego, utrzymanie się tego typu struktury eksportu było wyrazem możliwości ówcze-

19 DzURP 1933, nr 49, poz. 384; A. Mania, Polityka administracji Franklina Roosevelta wobec Związku Radzieckiego w latach 1933-1939, Kraków 1982, s. 34, 37.

20 Archiwum Akt Nowych w Warszawie (dalej: AAN), Ministerstwo Spraw Zagranicznych (dalej: MSZ), sygn. 429, k. 37, 8.

21 „Mały Rocznik Statystyczny”, 1939, s. 7.

22 Polsko-amerykańskie kontakty gospodarcze, „Trybuna Ludu” 1959, nr 212 z 3 VIII, s. 5-6.

23 W. Jurasz, Wptyw zagranicznej polityki ekonomicznej..., s. 40. 
snej ekonomiki Polski. Mając na uwadze, że udział polskiego eksportu do USA w latach 1950-1952 nie osiągnął poziomu sprzed wojny, trzeba zaznaczyć że wyniki całego polskiego eksportu w omawianych latach były ściśle związane z sytuacją na rynku węglowym, jako że węgiel stanowił np. w 1950 r. aż około $40,1 \%$ polskiego eksportu ogółem, z dalszą tendencją wzrostu w czasie realizacji planu 6-letniego, podczas gdy porównawczo w $1937 \mathrm{r}$. stanowił on 16,5\% eksportu ogółem ${ }^{24}$.

Oprócz węgla, ubogi wachlarz eksportowy Polski do USA w latach 1946-1949 obejmował cynk i tekstylia. Jednak z czasem asortyment towarów eksportowych uległ poszerzeniu. Od 1950 r., kiedy w Polsce wzrósł poziom uprzemysłowienia, wśród asortymentu wysyłanego do Stanów Zjednoczonych znalazły się różne maszyny, obrabiarki, urządzenia górnicze, statki morskie, a nawet kompletne obiekty przemysłowe ${ }^{25}$.

Tabela 1. Eksport Polski do USA w latach 1946-1952

\begin{tabular}{|l|c|c|c|c|}
\hline \multicolumn{1}{|c|}{ Lata } & 1946 & 1949 & 1950 & 1952 \\
\hline Eksport do USA w mln \$ & 0,3 & 4,1 & 11,2 & 11,25 \\
Udział \% eksportu Polski do USA & 0,3 & 0,7 & 1,8 & 1,5 \\
\hline
\end{tabular}

Źródło: AAN, MSZ, sygn. 429, k. 40.

W latach 1945-1960 oficjalna doktryna polityczna USA operowała dwoma konsekwentnymi hasłami z dziedziny „strategii politycznej”. Tuż po II wojnie światowej przyjęto hasło zatrzymania komunizmu w granicach Europy Wschodniej (policy of containment), które w latach 1948/49, po blokadzie Berlina, a zwłaszcza w trakcie konfliktu koreańskiego, przerodziło się w cel strategiczny w postaci „wyzwolenia narodów ujarzmionych” (liberation of captive nations). Istotną rolę odegrała tu polityka tzw. „,containment i liberation” propagowana przez senatora i późniejszego prezydenta USA John F. Kennedy'ego ${ }^{26}$. Koncepcje te wywarły oczywiście duży wpływ na kształtowanie się polityki ekonomicznej USA względem Polski. W latach 1945-1948 do pierwszej wielkiej konfrontacji politycznej na linii Wschód-Zachód i blokady Berlina, polityka ekonomiczna Stanów Zjednoczonych nie stwarzała utrudnień dla eksportu z Polski do USA ${ }^{27}$. W latach 1948-1950, pomimo że nadal stosowano w pełni „klauzulę najwyższego uprzywilejowania" wobec eksportu Polski do USA i pomimo, że oficjalna

\footnotetext{
24 AAN, MSZ, sygn. 429, k. 41.

25 Ibidem, Komitet Centralny Polskiej Zjednoczonej Partii Robotniczej (dalej: KC PZPR), Wydział Zagraniczny, sygn. 237/XXII-996, k. 86.

26 J. F. Kennedy, The Strategy of Peace Harper and Brothers, New York 1960, s. 83.

27 W. Jurasz, Wpływ zagranicznej polityki ekonomicznej..., s. 42-43.
} 
doktryna polityki handlowej nie dyskryminowała polskiego eksportu - czynniki pozaekonomiczne zaczęły mieć coraz silniejszy wpływ na sytuację polskiego eksportu. Od blokady Berlina miało miejsce coraz częstsze zjawisko bojkotu handlu ze Związkiem Radzieckim i jego krajami satelickimi, w tym i z Polską. Akcja ta przybierała formy bojkotu statków z Polski i innych krajów socjalistycznych, a także bojkotu towarów z państw komunistycznych. Bojkotowanie polskich statków rozpoczął w 1949 r. antykomunistyczny związek zawodowy dokerów „International Longshormen Association”, koncentrując akcje na statku MS „Batory”. Już w 1950 r. robotnicy portowi utrudniali wyładunek towarów polskich, co spotykało się z protestami Ambasady Polski w Waszyngtonie do Sekretarza Stanu USA. Stosowanie dyskryminacji wobec załogi, pasażerów i ładunku było niewątpliwie zachętą dla robotników portowych dla ogłoszenia bojkotu zarówno w stosunku do „Batorego” jak i w ogóle towarów nadchodzących z Polski. Wart podkreślenia jest fakt, że polityka ta stanowiła pożywkę dla akcji bojkotowych ${ }^{28}$. Pomimo przyjęcia przez ultra-konserwatywne organizacje w Stanach Zjednoczonych rezolucji zalecających bojkotowanie towarów z krajów komunistycznych, akcje tego typu nie zyskały jednak szerszego poparcia wśród obywateli amerykańskich ${ }^{29}$.

Mimo iż akcja bojkotowa nie wyrządziła poważniejszych szkód materialnych dla strony polskiej, tym niemniej klimat polityczny, który powstał wokół handlu z krajami socjalistycznymi, nie ułatwił dalszej ekspansji eksportu na ten rynek i był czynnikiem, który w znacznym stopniu wpłynął na decyzję o odebraniu „klauzuli najwyższego uprzywilejowania” w $1951 \mathrm{r}^{30} \mathrm{~W}$ nocie z 5 VII $1951 \mathrm{r}$. Sekretarz Stanu USA wystąpił z wnioskiem o zakończenie działania artykułu VI „Traktatu o Przyjaźni, Handlu i Prawach Konsularnych” między Polską a USA, zawartego przed wojną. Nota polska z sierpnia 1951 r. stwierdziła, co następuje: Przedstawiając rządowi polskiemu propozycje usunięcia artykułu VI $i$ wypowiadając całość traktatu $w$ razie jego nieprzyjęcia, rząd USA dobrze zdaje sobie sprawe z tego, że wspomniany artykut stanowi trzon tego traktatu i zawiera najważniejsze jego postanowienia. Jasne jest, że w rzeczywistości rzqd USA usituje wywołać wrażenie, że nie chodzi tu o zerwanie jeszcze jednego traktatu międzynarodowego, a tylko o jego modyfikację $e^{31}$.

Po odrzuceniu przez Polskę propozycji modyfikacji traktatu, rząd USA zerwał go dnia 5 I 1952 r. ${ }^{32}$ Polska formalnie straciła prawo korzystania z przywilejów „klauzuli najwyższego uprzywilejowania”, co oznaczało w praktyce nało-

28 AAN, MSZ, sygn. 429, k. 8-15.

29 „New York Times” 1950, nr 22 z 1 IX, s. 9.

30 E. Rubin, Flow of Trade With Poland on Rise, Interest in US Goods High, „Foreign Commerce Weekly" 1960, nr 25 (vol. 65) z 19 XII, s. 3.

31 AAN, MSZ, sygn. 431, k. 7-10.

32 Ibidem, KC PZPR, Wydział Zagraniczny, sygn. 237/XXII-1621, k. 193. 
żenie na poważną część polskiego eksportu, zwłaszcza na towary pochodzenia przemysłowego, protekcjonistycznych stawek celnych z reguły o $100 \%$ wyższych niż stawki przy posiadaniu „klauzuli najwyższego uprzywilejowania”. Od tej chwili przez 15 lat (przystąpienia Polski do Układu Ogólnego w sprawie Taryf Celnych i Handlu „GATT”) stosunki gospodarcze pomiędzy Polską a USA nie były uregulowane traktatem i porozumieniem międzynarodowym. Przy czym, nie ukrywano motywów politycznych odebrania Polsce tej klauzuli ${ }^{33}$. Ustawa o przedłużaniu umów handlowych z 1951 r. w sekcji 5 stanowiła, co następuje: Prezydent podejmie, tak szybko jak to jest możliwe, taka akcje jaka jest konieczna do zawieszenia, wycofania lub zapobieżenia stosowania jakiejkolwiek redukcji w jakiejkolwiek stawce celnej, w stosunku do importu ze Związu Socjalistycznych Republik Radzieckich, i do importu z jakiegokolwiek narodu lub terytorium pod dominacja lub kontrolowanego przez obcy rząd lub zagraniczna organizację kontrolujaca światowy ruch komunistyczny ${ }^{34}$. Klauzuli pozbawiono wszystkie kraje socjalistyczne z wyjątkiem Jugosławii. Decyzja władz USA sprawiła, że polski eksport do tego kraju musiał pokonywać protekcjonistyczną barierę celnąis.

Anulowanie klauzuli wpłynęło na osłabienie importu do Polski z USA, a eksport praktycznie wykazywał tendencję wzrostową tylko w przetworach mię$\operatorname{snych}^{36}$. Z uwagi na wysoki poziom ceł Polska nie mogła konkurować $\mathrm{z}$ innymi krajami korzystającymi na rynku amerykańskim z przywilejów. Zatem rozszerzenie list asortymentu eksportowego było bardzo trudne. Produkty mięsne w pierwszej połowie lat pięćdziesiątych oferowane dla USA ze strony Polski, były w zasadzie głównym towarem eksportowym. Znaczny wzrost ich eksportu opiewał na sumę od 1,5 mln w 1949 r. do 16,7 mln dolarów w roku 1956. Wśród innych artykułów wymienić należy pierze i puch, benzol, ozdoby choinkowe, naftalen prasowany, szczecinę oraz tkaniny lniane. Jeśli chodzi o import z USA do Polski, w latach 1952-1954 składały się na niego głównie szmaty wełniane, w 1955 r. doszły fosforyty i łój techniczny, a w 1956 r. po raz pierwszy od sześciu lat Polska kupiła niewielkie ilości bawełny za około 200 tys. dolarów ${ }^{37}$.

Wydarzenia roku 1956 wpłynęły na politykę handlową USA i Polski. Koniec systemu stalinowskiego w Polsce, referat Chruszczowa wygłoszony na XX Zjeździe KPZR i krytyka „kultu jednostki”, następnie śmierć Bieruta, zmiana na stanowisku I sekretarza PZPR którym został Gomułka, nagłaśniana demokratyzacja i liberalizacja życia publicznego, miały bardziej otworzyć Polskę na Za-

33 Ibidem, MSZ, sygn. 429, k. 42.

34 US Tariff Commission, „Trade Agreements Manual” 1959, s. 9.

35 AAN, KC PZPR, Wydział Zagraniczny, sygn. 237/XXII-1621, k. 13-16.

36 Polsko-amerykańskie kontakty gospodarcze...

37 AAN, MSZ, sygn. 428, k. 30-33. 
chód. Mimo że na przestrzeni 1956 r. eksport Polski do USA wzrósł o prawie 1 mln dolarów, co uznano za niezadowalające, to w 1957 r. obrót ten osiągnął już 25,7 mln dolarów. Wszystkie wyżej wymienione aspekty wpłynęły na prowadzone między Polską a Stanami Zjednoczonymi porozumienia w sprawie nowych umów handlowych ${ }^{38}$ i kredytów na zakup nadwyżek rolnych przez Polskę ${ }^{39}$.

W dniu 8 VI 1957 r. zawarto porozumienie o sprzedaży Polsce przez USA zboża, bawełny, tłuszczów i olei, oraz maszyn górniczych na sumę 48,9 mln dolarów. Najważniejsze z zobowiązań dotyczyły możliwości sprzedaży Polsce nadwyżek rolnych i innych towarów przez Korporację Kredytu Towarowego za dolary ${ }^{40}$. W 1958 r. dobiegła końca realizacja umów kredytowych. Polska otrzymała od Stanów Zjednoczonych w ramach tzw. długoterminowych kredytów: 457 tys. ton pszenicy, około 48 tys. ton nasion, 36 tys. ton bawełny i 16 tys. ton łoju. Dostawy Stanów Zjednoczonych pokryły deficyt zbożowy w Polsce, wpływając jednocześnie na lepsze zaopatrzenie przemysłu oraz złagodzenie trudności surowcowych, jakie gospodarka polska odczuwała od pewnego czasu ${ }^{41}$. Kolejny układy kredytowy oraz układ o sprzedaży za walutę polską produktów rolnych między Polską a USA zawarto w czerwcu 1959 r. W zamian za udzielenie Polsce 6 mln dolarów, zobowiązała się ona zakupić od USA 200 tys. ton pszenicy, 200 tys. ton jęczmienia, 11,5 ton kukurydzy, 70,5 tys. bel bawełny, 15 tys. ton oleju sojowego lub bawełnianego, i 5 tys. ton odtłuszczonego mleka w proszku ${ }^{42}$.

Przy znacznym ożywieniu wzajemnych kontaktów poprawił się też poziom eksportu Polski do USA. Ogółem do 1960 r. w ciągu siedmiu lat nastąpił trzykrotny jego skok ${ }^{43}$. Fakt, że rozwój eksportu odbywał się częściowo w warunkach dyskryminacji celnej, zaważył na jego strukturze, która nie odpowiadała możliwościom produkcyjnym kraju. Sytuacja Polski uległa zasadniczej zmianie w 1961 r. w związku z odzyskaniem przez nią ,klauzuli najwyższego uprzywilejowania" 44 . Zatem znów towary eksportowane do USA przez Polskę zwolniono z opłaty celnej. Wzrost tego eksportu w latach pięćdziesiątych XX w. niewątpliwie ułatwiła istniejąca tradycja wysyłania polskich szynek jeszcze sprzed II wojny światowej. Skala procentowa eksportu szynek do USA w stosunku do ogółu towarów eksportowanych wyglądała następująco: r. 1953 - 75,5\%, r. $1954-81,3 \%$,

38 Ibidem, KC PZPR, Sekretariat, sygn. XIA/61, k. 16-17, 25-31.

39 Agencja UP o stosunkach gospodarczych USA - Polska, ,Trybuna Ludu” 1957, nr 84 z 27 III, s. 4.

40 Polsko-amerykańskie porozumienie gospodarcze, ibidem, nr 156 z 9 VI, s. 3.

41 Jak wykorzystywane sq kredyty amerykańskie, ibidem, 1958, nr 24 z 25 I, s. 2.

42 Nowy uktad kredytowy Polska-USA, ibidem, 1959, nr 160 z 12 VI, s. 4.

43 AAN, MSZ, sygn. 429, k. 51.

44 „Federal Register” 1960, nr 237 z 7 XII, s. 2-3. 
r. $1957-75,9 \%$, r. $1960-57,8 \%{ }^{45}$. Przy czym, w latach pięćdziesiątych polityka handlowa Stanów Zjednoczonych dyskryminowała import z Polski w efekcie odebrania „klauzuli najwyższego uprzywilejowania”. Spowodowało to od $1962 \mathrm{r}$. widoczne przez pięć lat osłabienie tempa polskiego eksportu do USA ${ }^{46}$.

Tabela 2. Eksport Polski do USA w latach 1953-1960

\begin{tabular}{|c|c|c|c|c|c|c|c|c|}
\hline Lata & 1953 & 1954 & 1955 & 1956 & 1957 & 1958 & 1959 & 1960 \\
\hline Eksport w mln \$ & 13,9 & 21,5 & 25,7 & 28,0 & 29,6 & 28,6 & 31,6 & 38,8 \\
\hline
\end{tabular}

Źródło: AAN, MSZ, sygn. 429, k. 51.

W 1961 r. po odzyskaniu przez Polskę ,klauzuli najwyższego uprzywilejowania" nie skończyły się problemy z jej wdrożeniem w życie, bo wprowadzono poprawkę do ustawy o rozwoju handlu, blokując tym samym udział państwom komunistycznym w wolnym obrocie ${ }^{47}$. Nie skończyły się tez problemy z zakupem nadwyżek rolnych przez Polskę. Mimo podpisania w latach 1957-1964 przez Polskę i USA siedmiu umów dotyczących produktów rolnych, nadwyżki uległy zmniejszeniu. Miało to związek z nieurodzajem w ZSRR, Europie Zachodniej i Japonii. Wpłynął on też na funkcjonowanie gospodarki USA i pogorszenie jej bilansu płatniczego. W latach 1963-1964 zakup nadwyżek rolnych przez Polskę od USA wynosił 1,5-2 mln ton zbóż rocznie ${ }^{48}$.

$\mathrm{W}$ drugiej połowie lat sześćdziesiątych XX w. priorytetowe sprawy gospodarcze współpracy USA z Polską, obejmowały spłaty kredytów w ramach umów o produktach rolnych opiewające z początkiem 1965 r. na sumę $532 \mathrm{mln}$ dolarów. W 1967 r. spłaty Polski wynosiły ogółem 20,1 mln dolarów, w 1968 spadły do sumy 12,7 mln, a w 1969 r. wynosiły około 7,8 mln dolarów ${ }^{49}$.

Eksport polski do USA z końcem lat sześćdziesiątych XX w. zamykał się sumą 87,6 mln dolarów w 1968 r. i sumą 85,2 mln dolarów w r. 1969. Spadek nie wiązał się z trudnościami w ulokowaniu towarów, lecz z brakiem masy towarowej, zwłaszcza szynki, konserw i wyrobów walcowanych. Natomiast zmniejszenie importu z USA do Polski z sumy 51,1 mln dolarów w 1968 r. do sumy 48,2 mln dolarów w r. 1969 pozwoliło wraz z dochodami z usług, spadków i przekazów dewizowych do Polski, wytworzyć w polskim bilansie płatniczym

\footnotetext{
45 Reapplication of Trade - Agreement Reductions In Import-Duty Rates to Imports from Poland, Washington 1961, s. 9.

46 W. Jurasz, Wplyw zagranicznej polityki ekonomicznej..., s. 56-57.

47 Report of the Senate Committee on Finance on the Trade Expansion Act of 1962. Report No 2059 z 14 IX 1962 r., s. 15.

48 AAN, KC PZPR, Sekretariat, sygn. XIA/62, k. 116-117.

49 Ibidem.
} 
nadwyżkę 53,5 mln dolarów. Zakres restrykcji eksportowych USA względem Polski był mniejszy niż wobec reszty krajów socjalistycznych ${ }^{50}$. Z końcem lat siedemdziesiątych ogólna suma umów licencyjnych na eksport do Polski wynosiła zaledwie około 330 tys. dolarów. Na taki stan rzeczy nie bez znaczenia miała wpływ struktura polskich zakupów w Stanach Zjednoczonych. Import maszyn i urządzeń z USA stanowił tylko 5\%, zatem Polska pod koniec lat sześćdziesiątych nie wykorzystywała amerykańskiego postępu technicznego ${ }^{51}$.

Od zakończenia II wojny światowej do roku 1960 polski eksport do Stanów Zjednoczonych przybrał zdecydowanie tendencję wzrostową. O ile w $1946 \mathrm{r}$. stanowił 0,3 mln dolarów, to w r. 1960 już 38,8 mln dolarów. Mimo kłopotów $\mathrm{z}$,klauzulą najwyższego uprzywilejowania” i dyskryminowaniem polskiego eksportu, w latach pięćdziesiątych był on na dość dobrym poziomie. Anulowanie Polsce klauzuli wywołało widoczne w latach 1961-1967, osłabienie polskiego eksportu do USA. W dodatku od lat siedemdziesiątych XX w. zmniejszył się ogólny udział Polski w światowych obrotach handlowych osiągając sumę około $1,1 \%$ mln dolarów ${ }^{52}$. Zatem strukturę polskiego eksportu do USA w dekadzie lat sześćdziesiątych XX w. charakteryzowała konieczność jego koncentracji w zasadzie na jednej grupie towarowej, i wypracowanie takiej jego struktury, która nie odpowiadałaby strukturze produkcji Polski pod koniec lat pięćdziesiątych. Od drugiej połowy lat pięćdziesiątych i „odwilży październikowej” polski eksport rósł szybciej niż import, a stosunki ekonomiczne z USA uległy zmianie. Sporą część polsko-amerykańskich obrotów objęły dostawy produktów rolnych, a od lat siedemdziesiątych XX w. miał miejsce wzrost znaczenia handlu zagranicznego, jednak głównie przez wzrost importu, w zdecydowanej większości finansowanego z zagranicznych kredytów.

\section{Polish export against US economic policy in 1945-1967}

The article presents a relatively unknown issue of Polish-US economic cooperation i.e. Polish export to this country during Bierut's and Gomułka's administrations. The chronology of the article is justified by the US policy, which in the years 1945-1967 can be divided into two periods: 1945-1960 and 1961-1967. It is to be stressed that these two periods differed a lot from each other and were characterized by different dynamics.

50 A. Mania, Détente i polityka Stanów Zjednoczonych wobec Europy Wschodniej - styczeń 1969 - styczeń 1981, Kraków 2003, s. 44-51.

51 Polityka Stanów Zjednoczonych wobec krajów socjalistycznych oraz bilateralne stosunki polsko-amerykańskie, „Biuletyn Tygodniowy MSZ” 1969, nr 32, s. 4, 9.

52 Polska. Gospodarka. Handel zagraniczny, http://encyklopedia.pwn.pl/haslo/4575030/polskagospodarka-handel-zagraniczny.html (07-01-2014). 
The text is based mainly on documents created by the Foreign Department of the Central Committee of the Polish United Workers' Party and by the Ministry of Foreign Affairs, which were deposited in the Central Archives of Modern Records in Warsaw. Auxiliary materials, such as statistical yearbooks, Journals of Laws of the Republic of Poland, English literature, newspapers and magazines, were also indispensable for the analysis of the problem.

The article presents Polish export to the US in figures interpreted by the author. The goal of the article is to show US economic policy towards Poland and an attempt to answer the question whether economic issues influenced political relations of the two countries.

Key words: Polish export, economic cooperation, US economic policy 